Article

\title{
Assessing Parameter Suitability for the Strength Evaluation of Intramolecular Resonance Assisted Hydrogen Bonding in o-Carbonyl Hydroquinones
}

\author{
Maximiliano Martínez-Cifuentes ${ }^{1, *(\mathbb{0})}$, Matías Monroy-Cárdenas ${ }^{2}$, Juan Pablo Millas-Vargas ${ }^{2}$, \\ Boris E. Weiss-López ${ }^{3}$ and Ramiro Araya-Maturana $2,4, *$ (D) \\ 1 Programa Institucional de Fomento a la Investigación, Desarrollo e Innovación, Universidad Tecnológica \\ Metropolitana, Ignacio Valdivieso 2409, Casilla 9845, Santiago 8940577, Chile \\ 2 Instituto de Química de Recursos Naturales, Universidad de Talca, Av. Lircay s/n, Casilla 747, Talca 3460000, \\ Chile; maty.monroy@gmail.com (M.M.-C.); jpmillas@utalca.cl (J.P.M.-V.) \\ 3 Departamento de Química, Facultad de Ciencias, Universidad de Chile, Las Palmeras 3425, Casilla 653, \\ Santiago 7800003, Chile; bweiss@uchile.cl \\ 4 Programa de Investigación Asociativa en Cáncer Gástrico (PIA-CG), Universidad de Talca, Talca 3460000, \\ Chile \\ * Correspondence: mmartinez@utem.cl (M.M.-C.); raraya@utalca.cl (R.A.-M.); \\ Tel.: +56-2-27877905 (M.M.-C.); +56-71-2200285 (R.A.-M.)
}

Academic Editor: Goar Sánchez

Received: 22 November 2018; Accepted: 8 January 2019; Published: 14 January 2019

check for updates

\begin{abstract}
Intramolecular hydrogen bond (IMHB) interactions have attracted considerable attention due to their central role in molecular structure, chemical reactivity, and interactions of biologically active molecules. Precise correlations of the strength of IMHB's with experimental parameters are a key goal in order to model compounds for drug discovery. In this work, we carry out an experimental (NMR) and theoretical (DFT) study of the IMHB in a series of structurally similar $o$-carbonyl hydroquinones. Geometrical parameters, as well as Natural Bond Orbital (NBO) and Quantum Theory of Atoms in Molecules (QTAIM) parameters for IMHB were compared with experimental NMR data. Three DFT functionals were employed to calculated theoretical parameters: B3LYP, M06-2X, and $\omega$ B97XD. O $\cdots \mathrm{H}$ distance is the most suitable geometrical parameter to distinguish among similar IMHBs. Second order stabilization energies $\Delta \mathrm{E}_{\mathrm{ij}}{ }^{(2)}$ from NBO analysis and hydrogen bond energy $\left(\mathrm{E}_{\mathrm{HB}}\right)$ obtained from QTAIM analysis also properly distinguishes the order in strength of the studied IMHB. $\Delta \mathrm{E}_{\mathrm{ij}}{ }^{(2)}$ from NBO give values for the IMHB below $30 \mathrm{kcal} / \mathrm{mol}$, while $\mathrm{E}_{\mathrm{HB}}$ from QTAIM analysis give values above $30 \mathrm{kcal} / \mathrm{mol}$. In all cases, the calculated parameters using $\omega B$ 97XD give the best correlations with experimental ${ }^{1} \mathrm{H}-\mathrm{NMR}$ chemical shifts for the IMHB, with $\mathrm{R}^{2}$ values around 0.89 . Although the results show that these parameters correctly reflect the strength of the IMHB, when the weakest one is removed from the analysis, arguing experimental considerations, correlations improve significantly to values around 0.95 for $\mathrm{R}^{2}$.
\end{abstract}

Keywords: hydroquinone; polyphenol; hydrogen bond; DFT; NBO; QTAIM

\section{Introduction}

Hydrogen bonding (HB) is generally described as a stabilizing electrostatic interaction with a partly covalent character. Some of the most direct experimental evidence of the HB formation is the deshielding of the hydrogen atom involved in the interaction, which is easily observed by NMR spectroscopy [1,2]. It is well known that intramolecular hydrogen bonding (IMBH) has a key role in determining the structure and properties of biologically-active molecules, and their study in model 
compounds is relevant in drug design [3-5]. For example, IMBH formation is determinant for passive membrane permeability of cyclic peptides [6] and in lipophilicity [7].

Any intramolecular hydrogen bonding IMHB is governed by the equilibrium between closed (IMHB) and open (no IMHB) forms. Consequently, the implementation of IMHB considerations in drug discovery programs requires experimental methodologies to assess the position of these equilibria, which are dependent on the strength of each IMBH [8]. The ${ }^{1} \mathrm{H}-\mathrm{NMR}$ spectroscopy is the most common tool to measure the propensity of compounds to form IMHBs, nevertheless, up to now the throughput of NMR, and other traditional methods, is limited in obtaining structure-activity relationships (SAR) and driving rapid cycles of compound optimization [8]. However, current computational chemistry allows one to assess, theoretically, the strength of IMBH through parameters such as the distance hydrogen-acceptor, the distance donor-acceptor, and the hydrogen bond angle [9]. Among the theoretical estimated parameters for the HB interaction, those from Natural Bond Orbital (NBO) and Quantum Theory of Atoms in Molecules (QTAIM) analysis [9-13] are the most popular. In this field, DFT methodologies have proven to be valuable tools to calculate molecular properties with an appreciably low computational time demand compared with ab initio methodologies.

Previously we have studied the properties of some ortho-carbonyl hydroquinones with capability to cross membranes and to reach the inner mitochondrial membrane. These compounds act either as oxidative phosphorylation (OXPHOS) uncouplers, complex I inhibitors, or exert both activities; as a consequence they exhibit antitumor [14-16] or antiplatelet effects [17], or both. Interestingly, small structural changes on the hydroquinone scaffold determine their biological activities [15]. All these molecules exhibit strong resonance assisted intramolecular hydrogen bonding, assessed by ${ }^{1} \mathrm{H}-\mathrm{NMR}$ spectrometry [18]. These compounds act either as weak acids into the mitochondrial membrane, or by losing a hydrogen atom (or alternatively losing an electron followed by deprotonation) to afford the corresponding semiquinone radical, which can interfere in cell signaling. The formation of IMHB plays a key role $[19,20]$ on both properties. IMHBs have shown appreciable effects on the antioxidant and electrochemical properties of hydroquinones and related phenols [21,22].

On the other hand, the $o$-carbonyl hydroquinone motif is present on natural products with different biological activities, such as the anticancer drugs doxorubicin and daunorubicin [23], acylnaphtohydroquinones [24], shikonin [25], and in peyssonol A [26].

The precise assessment of the strength of the IMBH interaction has many difficulties. Determination of the H-bond energy is possible only for the intermolecular hydrogen bond: the energy of the intermolecular interaction is usually equal to the energy required to separate the two interacting molecules [1]. However, there is no clear definition of the hydrogen bond energy for the IMHB because the interacting entities cannot be fully separated [27].

Moreover, it is relatively easy to roughly calculate the relative strength of a series of IMBHs when they take place in molecules with large structural differences; however, to assess the relative strength of IMBHs in very similar molecules, establish correlations with experimental parameters, and use these data to make correlations with biological activities, requires an adequate choice of theoretical methodologies.

The aim of this work is to study the IMHBs experimentally and theoretically in a series of structurally similar o-carbonyl hydroquinones. Calculated NBO and QTAIM parameters of the IMHBs obtained by different DFT functionals (B3LYP, M06-2X, and $\omega$ B97XD) will be correlated with experimental values obtained by NMR.

\section{Results}

The studied compounds were synthesized according to Scheme $1[28,29]$. Starting from hydroquinone (1) or 2,3-dimethylhydroquinone (2), the corresponding acylhydroquinones (3-5) were obtained by Fries rearrangement [30]. These compounds were oxidized with silver (I) oxide to obtain the corresponding quinones (6-8), which were not isolated. These quinones yield benzofurans (12-17) by reaction with the enamines (9-11). The last step involves an acid rearrangement of these 
benzofurans, yielding the corresponding bicyclic hydroquinones (18, 20, 22-24). Monomethyl ethers of hydroquinone 19 and 21 were obtained by methylation of hydroquinones 18 and 20, respectively; they were synthesized to assess the effect of blocking the hydroxyl group not involved in IMHB.
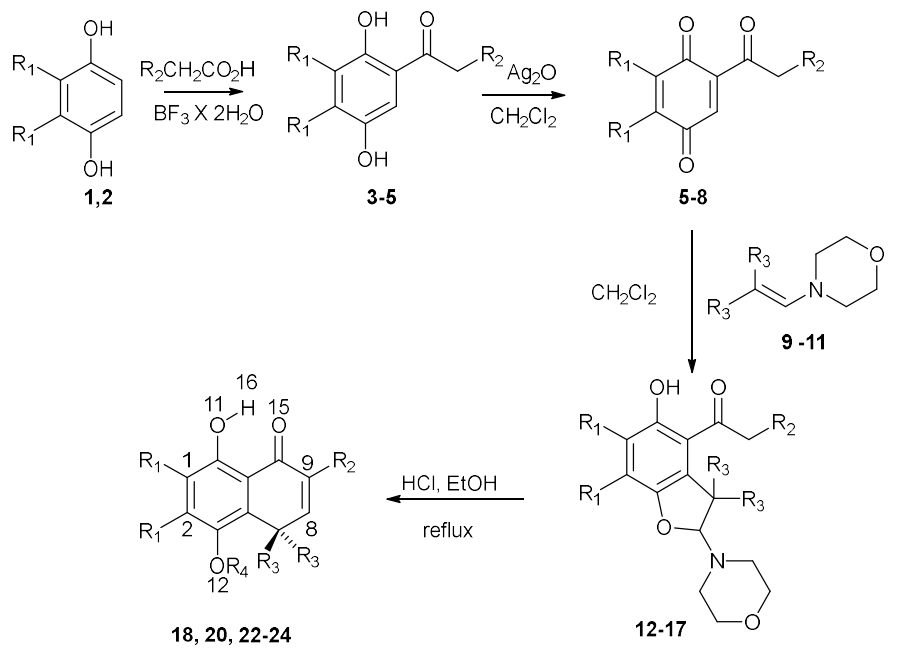

\begin{tabular}{ccccc}
\hline Hydroquinone & $\mathbf{R}_{\mathbf{1}}$ & $\mathbf{R}_{\mathbf{2}}$ & $\mathbf{R}_{\mathbf{3}}$ & $\mathbf{R}_{\mathbf{4}}$ \\
\hline $\mathbf{1 8}^{[31]}$ & $\mathrm{H}$ & $\mathrm{H}$ & $\mathrm{Me}$ & $\mathrm{H}$ \\
$\mathbf{1 9}^{\mathrm{a}}[31]$ & $\mathrm{H}$ & $\mathrm{H}$ & $\mathrm{Me}$ & $\mathrm{Me}$ \\
$\mathbf{2 0}^{\mathbf{b}}$ & $\mathrm{Me}$ & $\mathrm{H}$ & $\mathrm{Me}$ & $\mathrm{H}$ \\
$\mathbf{2 1}^{\mathrm{b}}$ & $\mathrm{Me}$ & $\mathrm{H}$ & $\mathrm{Me}$ & $\mathrm{Me}$ \\
$\mathbf{2 3}^{2}[32]$ & $\mathrm{H}$ & $\mathrm{Me}$ & $\mathrm{Me}$ & $\mathrm{H}$ \\
$\mathbf{2 4}^{2}[15,33]$ & $\mathrm{H}$ & $\mathrm{H}$ & $-\mathrm{CH}_{2}-\left(\mathrm{CH}_{2}\right)-\mathrm{CH}_{2-}$ & $\mathrm{H}$ \\
\hline
\end{tabular}

Note: ${ }^{\mathrm{a}}$ Obtained by methylation of $18,{ }^{\mathrm{b}}$ obtained by methylation of 20.

Scheme 1. Synthesis of the bicyclic hydroquinones studied in this work.

Three hybrid functional were employed in this work: B3LYP, composed of Becke three parameters hybrid functional B3 and the non-local correlation functional of Lee, Yang, and Parr (LYP) [34-36]. The second corresponds to a hybrid meta-generalized gradient-approximation (hybrid meta-GGAs) functional, M06-2x, which have been described as one the of the best Truhlar group functionals for non-covalent interactions [37]. The last functional corresponds to the long-range corrected functional $\omega B 97 X D$, which is designed to avoid rapid die-off of the non-coulomb part of the exchange functionals, which affects the modelling of long distance processes [38].

In this first part, we study main geometrical parameters from the IMHBs and their correlation with ${ }^{1} \mathrm{H}-\mathrm{NMR}$ chemical shifts. The results are presented in Table 1 . Calculations were carried out at DFT level using the B3LYP, M06-2X, and wB97XD functionals with the 6-311++g(d,p) basis set. Among the geometrical parameters, only the $\mathrm{O} 15 \cdots \mathrm{H} 16$ distances displayed enough differentiation to be used as comparison parameters for correlation with the chemical shifts of chelated protons. Compound 21 displayed the largest chemical shift and a more de-shielded proton, indicating the strongest IMHB, followed in strength by 20 . The later indicates that methyl substituents on $\mathrm{C} 1$ and $\mathrm{C} 2$ increase the IMHB strength. Additionally, the methylation at $\mathrm{O} 12$ and also a methyl group at C9 increase the strength of the IHB in 21 and 22, respectively. The three functionals give the shortest O15 * H16 distance for 21, indicating the strongest IHB, which is in agreement with the largest downfield chemical shift. The smallest chemical shift for 18 indicates the weakest IHB in the series. Nevertheless none of the three functional gives the largest $\mathrm{O} 15 \cdots \mathrm{H} 16$ distance for 18. These discrepancies can reflect the presence of intermolecular interactions competing with the IMHB, contributing in a non-negligible degree to the ${ }^{1} \mathrm{H}-\mathrm{NMR}$ spectra at the probe temperature, especially between pairs of molecules where 
one phenolic hydroxyl is replaced by a methoxy group. The same considerations can be applied to correlations with the next parameters. Global correlation among the chemical shift and O15 $\cdots$ H16 distance for all molecules were carried out (Figure 1). Results indicate that the $\omega$ B97XD functional gives the best correlation with an $R^{2}=0.89$, followed by M06- $2 X$ with a $R^{2}=0.85$ and B3LYP, and the worst correlation with $\mathrm{R}^{2}=0.80$.

Table 1. Experimental chemical shifts $(\delta)$ in ppm of protons involved in hydrogen bonding, and main geometric calculated parameters. Distances in angström, $(\AA)$, and angles in degree $\left(^{\circ}\right)$.

\begin{tabular}{|c|c|c|c|c|c|c|c|c|c|c|}
\hline \multirow{2}{*}{ Molecule } & \multirow{2}{*}{$\delta \mathrm{ppm}$} & \multicolumn{3}{|c|}{ Distance $\left(\mathrm{O}_{15} \cdots \mathbf{H}_{16}\right)$} & \multicolumn{3}{|c|}{ Distance $\left(\mathrm{O}_{11}-\mathrm{H}_{16}\right)$} & \multicolumn{3}{|c|}{ Angle $\left(\mathrm{O}_{15} \cdots \mathrm{H}_{16}-\mathrm{O}_{11}\right)$} \\
\hline & & B3LYP & M062x & $\omega B 97 X D$ & B3LYP & M062x & $\omega B 97 X D$ & B3LYP & M062x & $\omega B 97 X D$ \\
\hline 18 & 12.540 & 1.657 & 1.694 & 1.674 & 0.99 & 0.98 & 0.982 & 148 & 146 & 147 \\
\hline 19 & 12.690 & 1.657 & 1.695 & 1.675 & 0.99 & 0.98 & 0.981 & 148 & 146 & 147 \\
\hline 20 & 13.200 & 1.639 & 1.662 & 1.645 & 0.992 & 0.983 & 0.984 & 149 & 147 & 148 \\
\hline 21 & 13.440 & 1.620 & 1.658 & 1.640 & 0.994 & 0.984 & 0.985 & 149 & 148 & 149 \\
\hline 22 & 12.930 & 1.660 & 1.691 & 1.666 & 0.99 & 0.98 & 0.982 & 148 & 146 & 147 \\
\hline 23 & 12.740 & 1.661 & 1.701 & 1.68 & 0.99 & 0.98 & 0.982 & 148 & 146 & 147 \\
\hline 24 & 12.800 & 1.654 & 1.69 & 1.672 & 0.99 & 0.981 & 0.982 & 148 & 146 & 147 \\
\hline
\end{tabular}
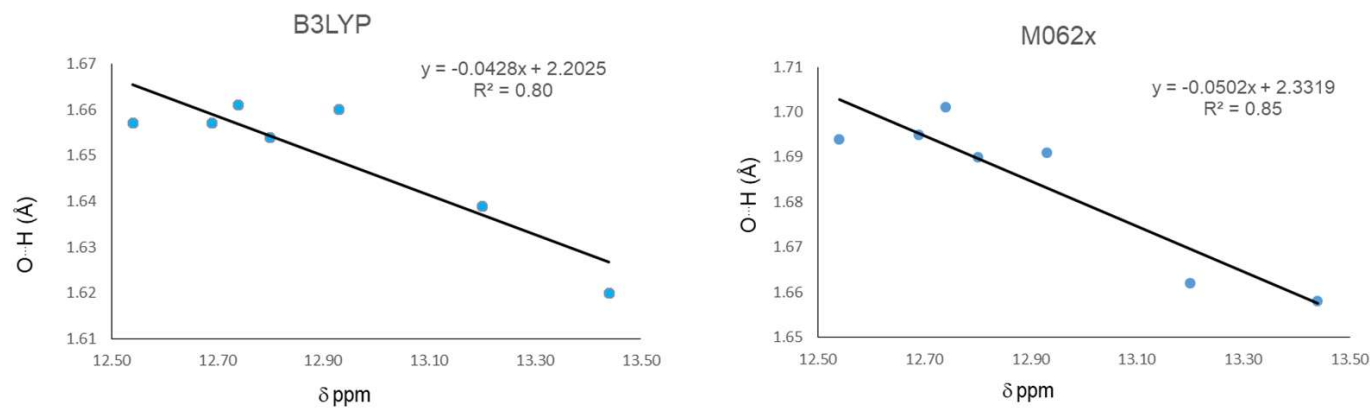

$\omega B 97 X D$

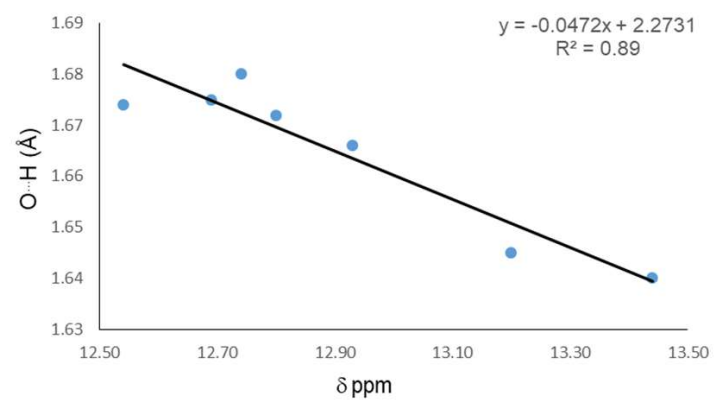

Figure 1. Correlations between $\mathrm{H} 16 \cdots \mathrm{O} 15$ distance and ${ }^{1} \mathrm{H}-\mathrm{NMR}$ chemical shifts $(\delta)$ for the hydrogen bond.

In order to estimate the energy of IMHB, the open-close method was employed, which defines the $\mathrm{H}$-bond energy as the difference between the open and close conformers $[39,40]$. Calculations were carried out with the functional $\omega \mathrm{B} 97 \mathrm{XD}$, which presents the best correlation between experimental chemical shift and O16 $\cdots$ H15 distance. Table 2 shows that energy for IMHB in the studied hydroquinones are around $15 \mathrm{kcal} / \mathrm{mol}$. Hydroquinone 20 presents the highest value, $16.37 \mathrm{kcal} / \mathrm{mol}$, while 19 presents the lowest IMHB energy, $14.22 \mathrm{kcal} / \mathrm{mol}$. These energy differences are large enough to discard the contribution of the open form to the experimental NMR shieldings. Figure 2 shows the correlation between Hydrogen bond energy $\left(\mathrm{E}_{\mathrm{HB}}\right)$ and ${ }^{1} \mathrm{H}-\mathrm{NMR}$ chemical shifts $(\delta)$, which presents a $R^{2}=0.71$, a value lower than the correlation with the $\mathrm{O}_{15} \cdots \mathrm{H}_{16}$ distance $\left(R^{2}=0.89\right)$, calculated with the same functional. 
Table 2. Hydrogen bond energy $\left(\mathrm{E}_{\mathrm{HB}}\right)$, calculated as the difference between open and close conformers. Energies in $\mathrm{kcal} / \mathrm{mol}$.

\begin{tabular}{cc}
\hline Molecule & $\mathbf{E}_{\mathbf{H B}}$ \\
\hline $\mathbf{1 8}$ & 14.34 \\
$\mathbf{1 9}$ & 14.22 \\
$\mathbf{2 0}$ & 16.37 \\
$\mathbf{2 1}$ & 15.71 \\
$\mathbf{2 2}$ & 14.44 \\
$\mathbf{2 3}$ & 14.36 \\
$\mathbf{2 4}$ & 14.52 \\
\hline
\end{tabular}

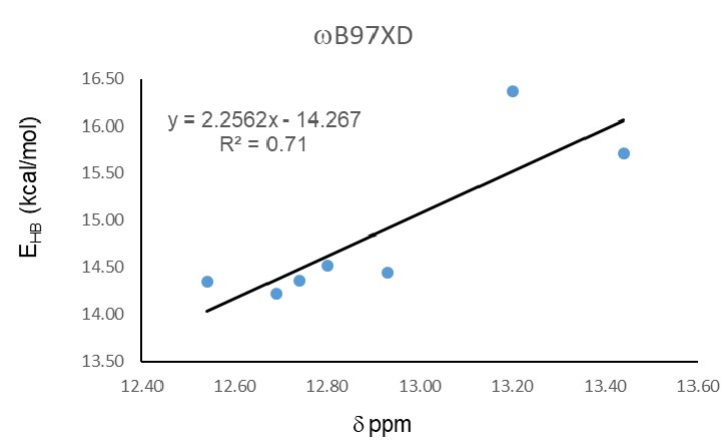

Figure 2. Correlation between Hydrogen bond energy $\left(\mathrm{E}_{\mathrm{HB}}\right)$ and ${ }^{1} \mathrm{H}-\mathrm{NMR}$ chemical shifts $(\delta)$.

The results from NBO analysis are presented in Table 3. Second order stabilization energies $\Delta \mathrm{E}_{\mathrm{ij}}{ }^{(2)}$ between donor $\left(\varphi_{\mathrm{i}}\right)$ and acceptor orbital $\left(\varphi_{\mathrm{j}}\right)$ allow one to study orbital interactions responsible for the IMHB. For all studied compounds, the HB donor atom is always an oxygen (two lone-pairs) and the acceptor is the antibonding sigma orbital of an $\mathrm{O}-\mathrm{H}$ groups $\left(\sigma^{*} \mathrm{OH}\right)$. As we found in the geometrical analysis, strong IMHB presence in $\mathbf{2 1}$ (the largest chemical shift) is in agreement with the largest $\Delta \mathrm{E}_{\mathrm{ij}}{ }^{(2)}$ obtained from the calculations with the three functionals. Nevertheless, $\Delta \mathrm{E}_{\mathrm{ij}}{ }^{(2)}$ did not predict well the weakest IMHB, corresponding to $\mathbf{1 8}$, and the lowest stabilization energy was not predicted by any of the three calculations using the studied functionals. Global correlation among the chemical shift and $\Delta \mathrm{E}_{\mathrm{ij}}{ }^{(2)}$ for all HQs were carried out (Figure 3). As in the geometrical analysis, correlation results indicate that the best correlation is obtained with the $\omega B 97 X D$ functional, with $R^{2}=0.89$. However, in this case it was followed by B3LYP with $R^{2}=0.87$ and then M06-2X, the one that gave the worst correlation with $\mathrm{R}^{2}=0.85$.

Table 3. Second order stabilization energies $\left(\Delta \mathrm{E}_{\mathrm{ij}}{ }^{(2)}\right)$ between donor $\mathrm{LP} \mathrm{O}_{15}$ and acceptor $\sigma^{*} \mathrm{O}_{11}-\mathrm{H}_{16}$ orbitals involved in the IMHB. Energies in $\mathrm{kcal} / \mathrm{mol}$.

\begin{tabular}{cccc}
\hline \multirow{2}{*}{ Molecule } & \multicolumn{3}{c}{$\Delta \mathrm{E}_{\mathbf{i j}}{ }^{(\mathbf{2})} \mathbf{L P ~}_{\mathbf{1 5}} \rightarrow \boldsymbol{\sigma}^{*} \mathbf{O}_{\mathbf{1 1}}-\mathbf{H}_{\mathbf{1 6}}$} \\
\cline { 2 - 4 } & $\mathbf{B} \mathbf{L Y P}$ & $\mathbf{M 0 6 - 2 X}$ & $\boldsymbol{\omega B 9 7 X D}$ \\
\hline $\mathbf{1 8}$ & 27.14 & 23.12 & 25.11 \\
$\mathbf{1 9}$ & 27.02 & 22.95 & 24.87 \\
$\mathbf{2 0}$ & 28.99 & 26.13 & 27.99 \\
$\mathbf{2 1}$ & 31.15 & 26.6 & 28.62 \\
$\mathbf{2 2}$ & 27.65 & 23.23 & 25.68 \\
$\mathbf{2 3}$ & 26.67 & 22.54 & 24.59 \\
$\mathbf{2 4}$ & 27.47 & 23.44 & 25.27 \\
\hline
\end{tabular}



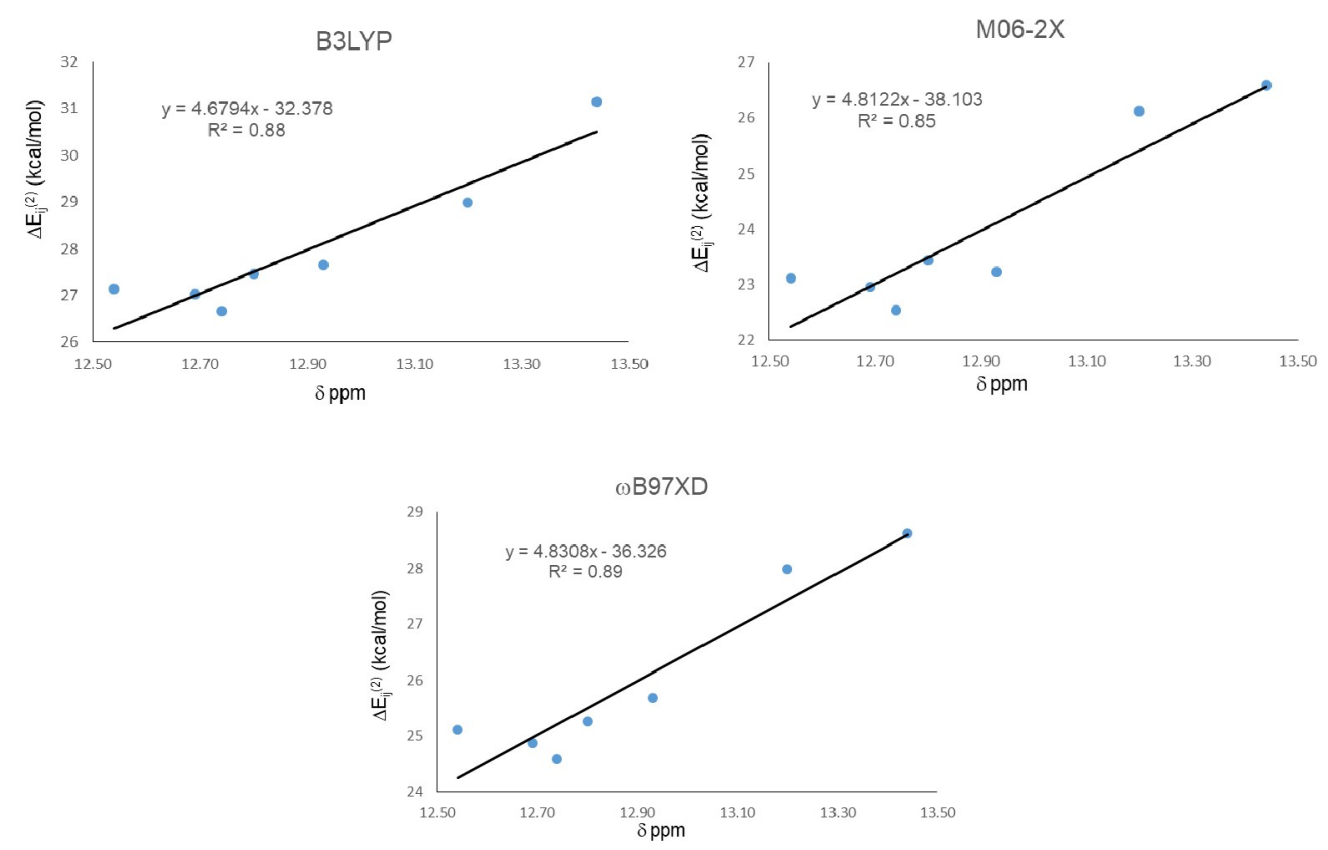

Figure 3. Correlations between second order stabilization energies $\Delta \mathrm{E}_{\mathrm{ij}}{ }^{(2)} \mathrm{LP} \mathrm{O}_{15} \rightarrow \sigma^{*} \mathrm{O}_{11}-\mathrm{H}_{16}$ and ${ }^{1} \mathrm{H}-\mathrm{NMR}$ chemical shifts ( $\delta$ ) for IMHB.

The QTAIM analysis is presented in Table 4. It shows negative values for $\nabla^{2} \rho$ and $\mathrm{H}$ for all studied compounds, indicating the covalent nature of their IHBs. IVI/G ratio is also a sensitive parameter for evaluating the covalency [41,42]. $\mathrm{V}$ can be interpreted as the pressure exerted on the electrons by the HB system, while G can be interpreted as the pressure exerted (as a reaction) by the electrons on the HB system, at the critical point. For negative values of $\nabla^{2} \rho$, as occurred in all our cases, values of $|\mathrm{V}| / \mathrm{G}>2$ were indicative of covalent interaction [2]. Hydrogen bond energy $\left(\mathrm{E}_{\mathrm{HB}}\right)$ was obtained from the potential energy density (V) [13]. All values were slightly above $30 \mathrm{kcal} / \mathrm{mol}$, while NBO analysis gave all energies slightly below $30 \mathrm{kcal} / \mathrm{mol}$ for the same interaction. These values were approximately twice those calculated by the open-close method, which indicates that NBO and AIM overestimate the interaction energy for the IMHB. $\mathrm{E}_{\mathrm{HB}}$ values calculated by different methods have shown to be generally inconsistent [43]. As we found in both geometrical and NBO analysis, the strongest IHB is obtained for compound $\mathbf{2 1}$ and is well represented by QTAIM analysis for the three functionals, giving the highest $\mathrm{E}_{\mathrm{HB}}$ for 21 . On the other hand, similarly to NBO analysis, here QTAIM $\mathrm{E}_{\mathrm{HB}}$ also did not adequately reflect the weakest IMHB present in 18. Global correlations between QTAIM $E_{\mathrm{HB}}$ and chemical shifts are presented in Figure 4. A better performance is shown by $\omega B$ 97XD and B3LYP with a $\mathrm{R}^{2}=0.88$. As in the above cases, M06-2X gave the worst correlation with $\mathrm{R}^{2}=0.85$.

The results shown in Figure 3 corroborates that correlations with the weakest IMHB of this series are not well represented by the computational calculations employed. In order to test what is the impact of the weakest IMHB on the correlations studied previously, compound $\mathbf{1 8}$ was eliminated from the data and correlations were obtained again. The results showed a significant improvement, without change in the relative position among different functionals and parameters studied. 
Table 4. Atoms-in-molecule parameters for IHB of 18-24. Electron density at the critical point $\rho^{\mathrm{BCP}}$ (a.u), its Laplacian $\nabla^{2} \rho$ (a.u.), electron kinetic energy density $G$ (a.u.), potential energy density V (a.u.), total electron energy density $\mathrm{H}$ (a.u.), and hydrogen bond energy $\mathrm{E}_{\mathrm{HB}}(\mathrm{kcal} / \mathrm{mol})$.

\begin{tabular}{ccccccccc}
\hline Functional & Molecule & $\mathbf{\rho}^{\mathbf{B C P}}$ & $\boldsymbol{\nabla}^{\mathbf{2}} \boldsymbol{\rho}$ & $\mathbf{G}$ & $\mathbf{V}$ & $\mathbf{I} \mathbf{V} / \mathbf{G}$ & $\mathbf{H}$ & $\mathbf{E}_{\mathbf{H B}}$ \\
\hline \multirow{6}{*}{ B3LYP } & $\mathbf{1 8}$ & 0.0537 & -0.0377 & 0.0459 & -0.1013 & 2.2070 & -0.1472 & 31.91 \\
& $\mathbf{1 9}$ & 0.0537 & -0.0378 & 0.0460 & -0.1015 & 2.2065 & -0.1475 & 31.96 \\
& $\mathbf{2 0}$ & 0.0560 & -0.0383 & 0.0478 & -0.1051 & 2.1987 & -0.1529 & 33.12 \\
& $\mathbf{2 1}$ & 0.0587 & -0.0392 & 0.0501 & -0.1100 & 2.1956 & -0.1601 & 34.65 \\
& $\mathbf{2 2}$ & 0.0546 & -0.0383 & 0.0469 & -0.1033 & 2.2025 & -0.1502 & 32.54 \\
& $\mathbf{2 3}$ & 0.0533 & -0.0374 & 0.0455 & -0.1003 & 2.2044 & -0.1457 & 31.59 \\
& $\mathbf{2 4}$ & 0.0541 & -0.0378 & 0.0463 & -0.1020 & 2.2030 & -0.1483 & 32.14 \\
\hline \multirow{6}{*}{ M06-2X } & $\mathbf{1 8}$ & 0.0454 & -0.0408 & 0.0444 & -0.0990 & 2.2297 & -0.1434 & 31.19 \\
& $\mathbf{1 9}$ & 0.0454 & -0.0409 & 0.0444 & -0.0990 & 2.2297 & -0.1434 & 31.19 \\
& $\mathbf{2 0}$ & 0.0490 & -0.0427 & 0.0479 & -0.1066 & 2.2255 & -0.1545 & 33.57 \\
& $\mathbf{2 1}$ & 0.0495 & -0.0428 & 0.0483 & -0.1074 & 2.2236 & -0.1557 & 33.83 \\
& $\mathbf{2 2}$ & 0.0458 & -0.0412 & 0.0449 & -0.1001 & 2.2294 & -0.1450 & 31.53 \\
& $\mathbf{2 3}$ & 0.0446 & -0.0402 & 0.0435 & -0.0970 & 2.2299 & -0.1405 & 30.57 \\
& $\mathbf{2 4}$ & 0.0459 & -0.0410 & 0.0448 & -0.0999 & 2.2299 & -0.1448 & 31.48 \\
\hline \multirow{6}{*}{ (2) } & $\mathbf{1 8}$ & 0.0510 & -0.0380 & 0.0447 & -0.0989 & 2.2125 & -0.1435 & 31.14 \\
& $\mathbf{1 9}$ & 0.0508 & -0.0381 & 0.0446 & -0.0987 & 2.2130 & -0.1434 & 31.10 \\
& $\mathbf{2 0}$ & 0.0546 & -0.0394 & 0.0479 & -0.1057 & 2.2067 & -0.1536 & 33.30 \\
& $\mathbf{2 1}$ & 0.0553 & -0.0396 & 0.0485 & -0.1069 & 2.2041 & -0.1553 & 33.66 \\
& $\mathbf{2 2}$ & 0.0518 & -0.0386 & 0.0457 & -0.1010 & 2.2100 & -0.1466 & 31.81 \\
& $\mathbf{2 3}$ & 0.0502 & -0.0376 & 0.0439 & -0.0973 & 2.2164 & -0.1412 & 30.64 \\
& $\mathbf{2 4}$ & 0.0512 & -0.0381 & 0.0449 & -0.0993 & 2.2116 & -0.1442 & 31.29 \\
\hline
\end{tabular}
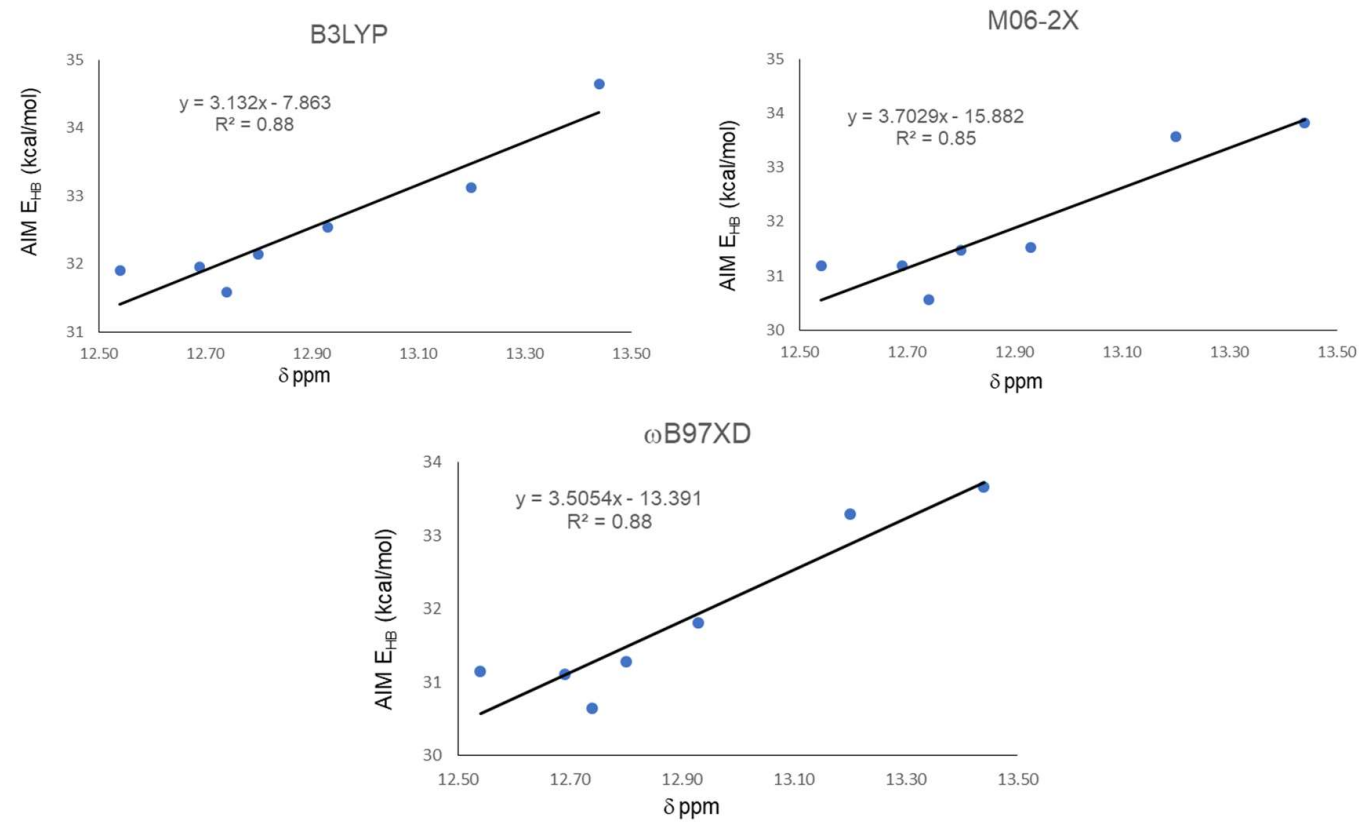

Figure 4. Correlations between hydrogen bond energy $\mathrm{E}_{\mathrm{HB}}(\mathrm{kcal} / \mathrm{mol})$ and experimental chemical shifts $\delta$ (ppm) of proton involved in IMHB.

Figure 5 shows correlations between ${ }^{1} \mathrm{H}-\mathrm{NMR}$ chemical shifts and $\mathrm{O} 11-\mathrm{H} 16 \cdots \mathrm{O} 15$ distance for the IHBs. $\mathrm{R}^{2}$ for B3LYP changed from 0.80 to 0.88 , from 0.85 to 0.91 for M06-2x, and from 0.89 to 0.95 for $\omega B 97 X D$. 

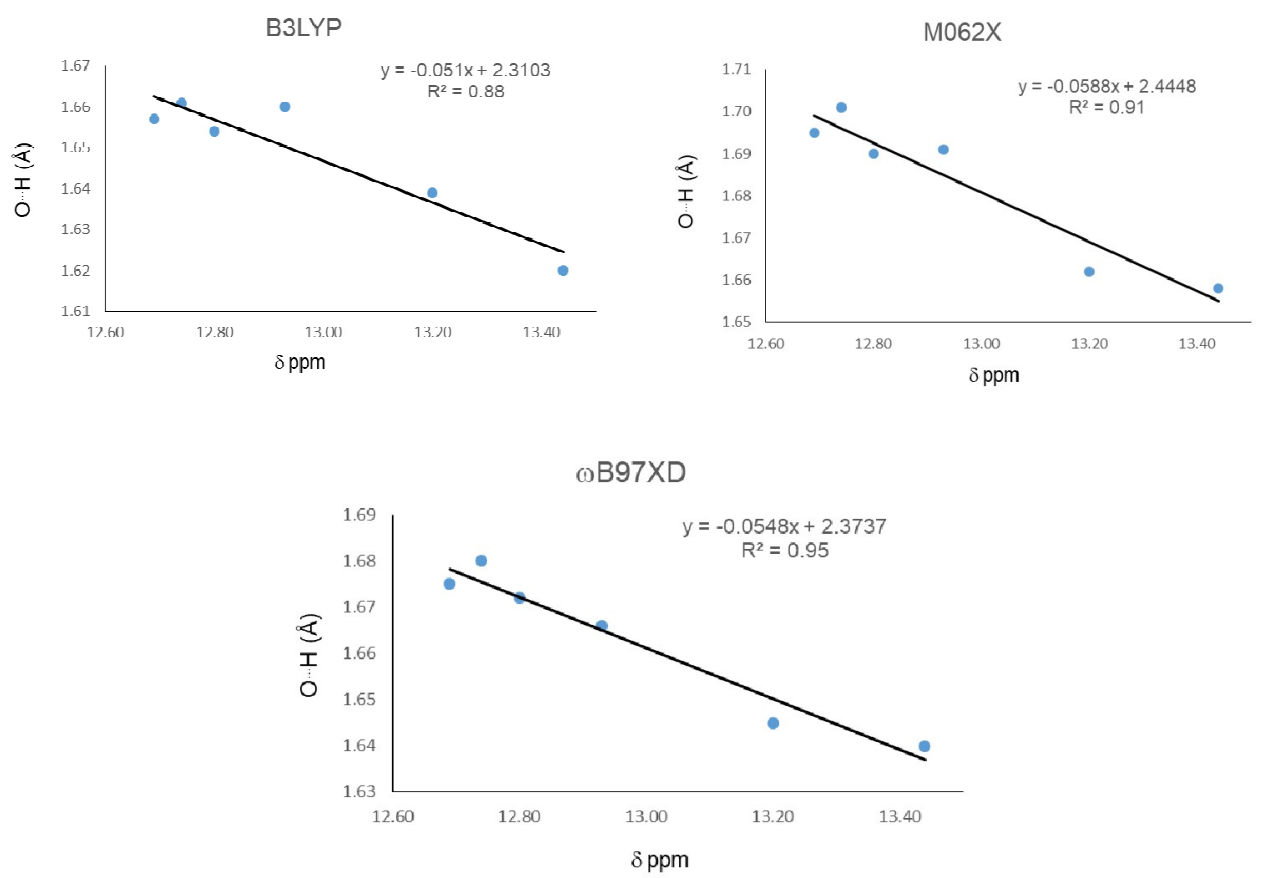

Figure 5. Correlations between $\mathrm{O}-\mathrm{H} \cdots \mathrm{O}$ distance and ${ }^{1} \mathrm{H}-\mathrm{NMR}$ chemical shifts $(\delta)$ for the IMHB, excluding the weakest value.

Similarly, correlations between ${ }^{1} \mathrm{H}-\mathrm{NMR}$ chemical shifts and NBO energy for the IHBs are presented in Figure 6. $\mathrm{R}^{2}$ changed from 0.88 to 0.95 for B3LYP, from 0.85 to 0.92 for M06-2X, and from 0.89 to 0.96 for $\omega \mathrm{B} 97 \mathrm{XD}$.
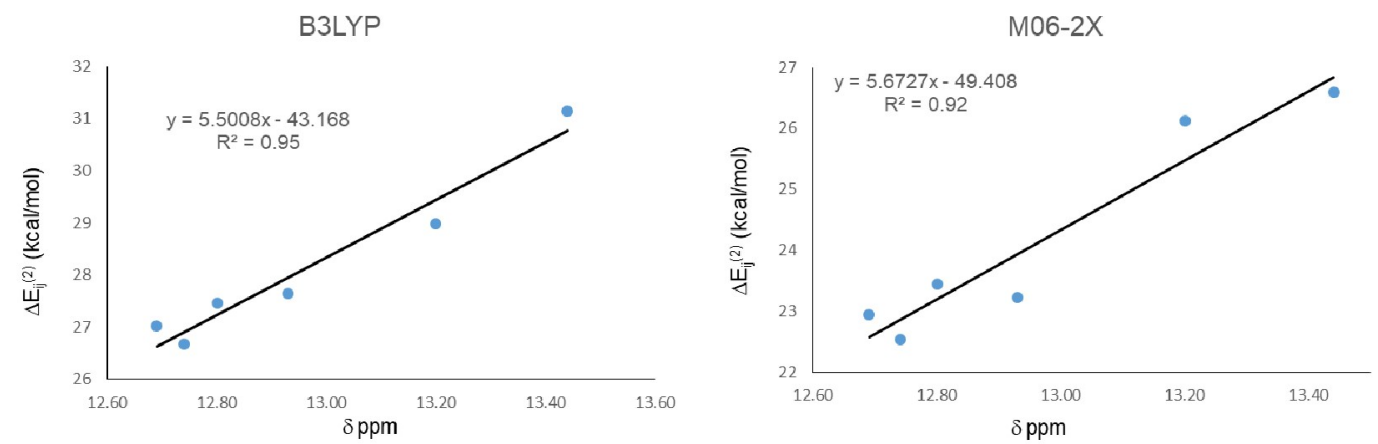

$\omega B 97 X D$

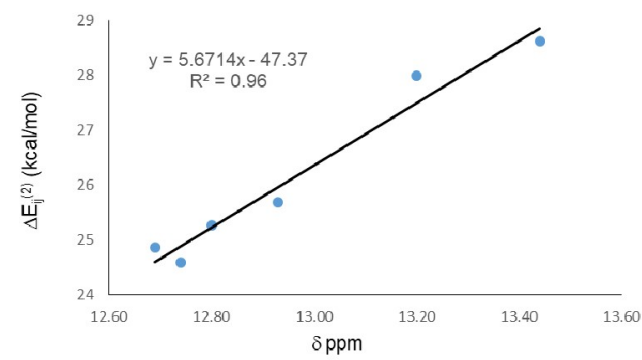

Figure 6. Correlations between second order stabilization energies $\Delta \mathrm{E}_{\mathrm{ij}}{ }^{(2)} \mathrm{LP} \mathrm{O}_{15} \rightarrow \sigma^{*} \mathrm{O}_{11}-\mathrm{H}_{16}$ and experimental chemical shifts $(\delta)$ of protons involved in IMHB, excluding the weakest value.

Finally, correlations between ${ }^{1} \mathrm{H}-\mathrm{NMR}$ chemical shifts and QTAIM energy for the IHBs, presented in Figure 7, showed a change in $\mathrm{R}^{2}$ from 0.88 to 0.94 for B3LYP, from 0.85 to 0.91 to M06-2X, and from 0.88 to 0.94 for $\omega B$ B7XD. 

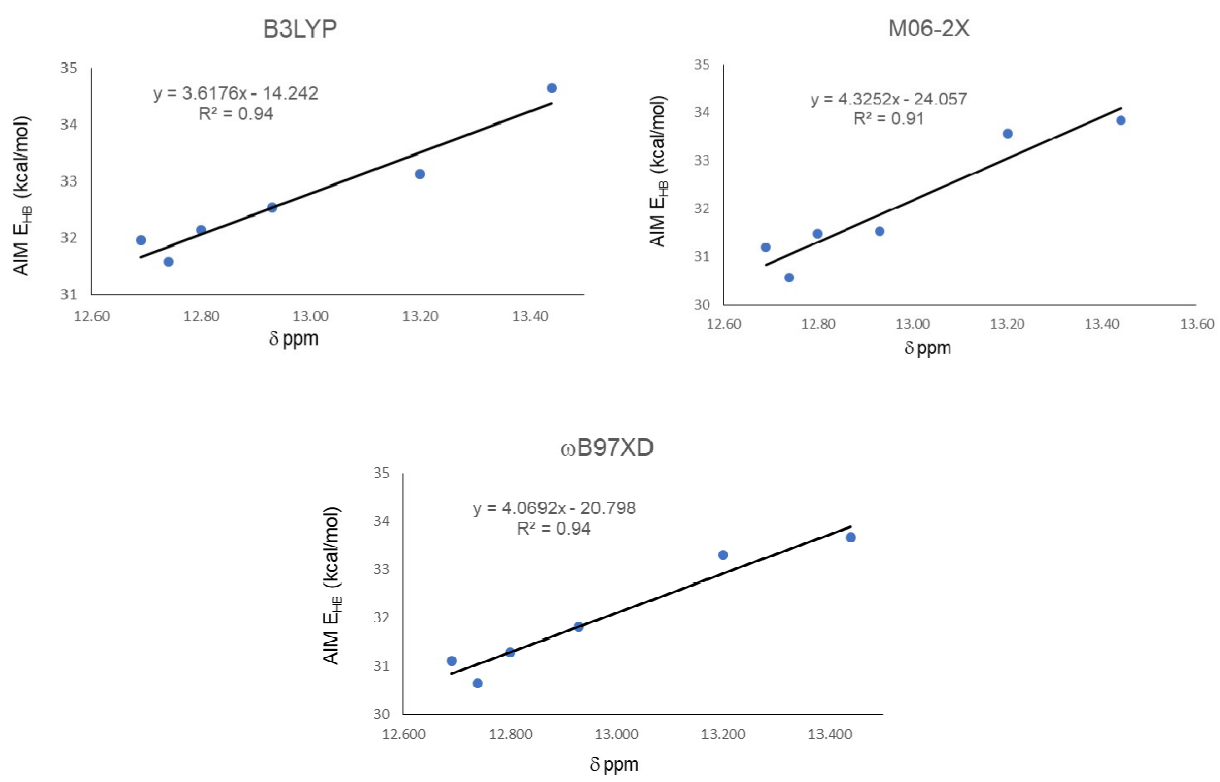

Figure 7. Correlations between hydrogen bond energy $\mathrm{E}_{\mathrm{HB}}(\mathrm{kcal} / \mathrm{mol})$ and experimental chemical shifts $\delta$ (ppm) of protons involved in IMHB, excluding the weakest value.

\section{Materials and Methods}

\subsection{Synthetic Procedures}

Melting points are uncorrected. All NMR spectra were acquired using a Bruker AVANCE DRX 300 spectrometer (Bruker BioSpin $\mathrm{GmbH}$, Rheinstetten, Germany) operating at $300.13 \mathrm{MHz}\left({ }^{1} \mathrm{H}\right)$ or $75.47 \mathrm{MHz}\left({ }^{13} \mathrm{C}\right)$. Measurements were carried out at a probe temperature of $300 \mathrm{~K}$.

\subsubsection{1-(5-Hydroxy-3,3,6,7-tetramethyl-2-morpholino-2,3-dihydrobenzofuran-4-yl)ethan-1-one (14)}

To a solution of 1-(2,5-dihydroxy-3,4-dimethylphenyl)ethan-1-one (400 mg, $2.2 \mathrm{mmol}$ ) in $20 \mathrm{~mL}$ of dichloromethane, $\mathrm{Ag}_{2} \mathrm{O}$ (1.28 g) was added and stirred with magnetic stirring for one hour. Then, the filtered solution was added over a solution of 4-(2-methylprop-1-en-1-yl)morpholine (314 mg, $2.2 \mathrm{mmol})$, in $\mathrm{CH}_{2} \mathrm{Cl}_{2}(10 \mathrm{~mL})$, yielding $637 \mathrm{mg}$ of the furan (14) $\left(2.0 \mathrm{mmol}, 90 \%\right.$ yield). ${ }^{1} \mathrm{H}-\mathrm{NMR}$ $\delta\left(\mathrm{CDCl}_{3}\right): 1.37\left(\mathrm{~s}, 3 \mathrm{H}, 3-\mathrm{CH}_{3}\right) ; 1.45\left(\mathrm{~s}, 3 \mathrm{H}, 3-\mathrm{CH}_{3}\right) ; 2.14\left(\mathrm{~s}, 3 \mathrm{H}, \mathrm{Ar}-\mathrm{CH}_{3}\right) ; 2.19\left(\mathrm{~s}, 3 \mathrm{H}, \mathrm{Ar}-\mathrm{CH}_{3}\right) ; 2.33-2.60$ $\left(\mathrm{m}, 4 \mathrm{H}, 2 \times \mathrm{CH}_{2}-\mathrm{O}\right) ; 2.61\left(\mathrm{~s}, 3 \mathrm{H}, \mathrm{CH}_{3} \mathrm{CO}\right) ; 3.70\left(\mathrm{~m}, 4 \mathrm{H}, 2 \times \mathrm{CH}_{2}-\mathrm{N}\right) ; 4.68(\mathrm{~s}, 1 \mathrm{H}, \mathrm{O}-\mathrm{CH}-\mathrm{N}) ; 7.09(\mathrm{~s}, 1 \mathrm{H}$, 5-OH). ${ }^{13} \mathrm{C}-\mathrm{NMR} \delta\left(\mathrm{CDCl}_{3}\right): 11.82 ; 12.51 ; 19.80 ; 31.17 ; 32.81 ; 45.07 ; 49.28 ; 66.75 ; 108.78 ; 120.94 ; 122.53$; 123.74; 128.69; 147.01; 150.86; 205.43. M.P.: $140.1-142 .{ }^{\circ} \mathrm{C}$. IR (KBr) v/ $\mathrm{cm}^{-1}: 842.77 ; 1684.89 ; 2836.66$; 2909.00; 2949.52; 2981.35; 3357.56. HRMS calculated: 319.1784; found: 319.1787.

\subsubsection{5,8-Dihydroxy-4,4,6,7-tetramethylnaphthalen-1(4H)-one (21)}

A solution of furan $14(451 \mathrm{mg}, 1.4 \mathrm{mmol})$ in ethanol $(15 \mathrm{~mL})$ was refluxed for $2 \mathrm{~h}$, then the solution was poured in a mixture ice and water, and the solid precipitate was filtered and dried yielding hydroquinone $21\left(256 \mathrm{mg}, 78 \%\right.$ yield). ${ }^{1} \mathrm{H}-\mathrm{NMR} \delta\left(\mathrm{CDCl}_{3}\right): 1.61\left(\mathrm{~s}, 6 \mathrm{H}, 2 \times 4-\mathrm{CH}_{3}\right) ; 2.23(\mathrm{~s}, 3 \mathrm{H}$, Ar- $\left.\mathrm{CH}_{3}\right) ; 2.26\left(\mathrm{~s}, 3 \mathrm{H}, \mathrm{Ar}-\mathrm{CH}_{3}\right) ; 4.55(\mathrm{~s}, 1 \mathrm{H}, 5-\mathrm{OH}) ; 6.23(\mathrm{~d}, 1 \mathrm{H}, J=10 \mathrm{~Hz}, 2-\mathrm{H}), 6.82(\mathrm{~d}, 1 \mathrm{H}, J=10 \mathrm{~Hz}$, 3-H), 13.20 (s, $1 \mathrm{H}, 8-\mathrm{OH}) .{ }^{13} \mathrm{C}-\mathrm{NMR} \delta\left(\mathrm{CDCl}_{3}\right): 11.56 ; 13.04 ; 25.17 ; 38.03 ; 112.68 ; 123.43 ; 124.04 ; 131.51$; 131.64; 143.52; 155.12; 160.73; 191.11. P.F.: $200.5-201.6{ }^{\circ} \mathrm{C}$. IR (KBr) $v / \mathrm{cm}^{-1}$ : 1658.84; 2963; 2998.71; 3406.75. HRMS calculated: 232.1099; found: 232.1113 .

\subsubsection{8-Hydroxy-5-methoxy-4,4,6,7-tetramethylnaphthalen-1(4H)-one (22)}

To a solution of hydroquinone $21(100 \mathrm{mg}, 0.43 \mathrm{mmol})$ in acetone $(20 \mathrm{~mL})$, powdered $\mathrm{K}_{2} \mathrm{CO}_{3}$ $(85 \mathrm{mg}, 0.6 \mathrm{mmol})$ and dimethyl sulfate $(0.1 \mathrm{~mL}, 0.6 \mathrm{mmol})$ were added and stirred with magnetic 
stirring at reflux for $3 \mathrm{~h}$. To the filtered mixture, a solution of $\mathrm{KOH}$ ( $5 \%$ in methanol) was added and kept at room temperature overnight. Then, it was neutralized with $\mathrm{HCl} 10 \%$ and extracted with $\mathrm{CH}_{2} \mathrm{Cl}_{2} 5 \times 20 \mathrm{~mL}$. The organic phase was washed with water and dried with anhydrous sodium sulfate, then was filtered and the solvent was eliminated at vacuum, by purification in flash column chromatography with hexane/ethyl acetate (5:1) as eluent, the product 22 was obtained $(79 \mathrm{mg}, 74 \%$ yield ${ }^{1} \mathrm{H}-\mathrm{NMR} \delta\left(\mathrm{CDCl}_{3}\right): 1.57\left(\mathrm{~s}, 6 \mathrm{H}, 2 \times 4-\mathrm{CH}_{3}\right) ; 2.20\left(\mathrm{~s}, 3 \mathrm{H}, \mathrm{Ar}-\mathrm{CH}_{3}\right) ; 2.31\left(\mathrm{~s}, 3 \mathrm{H}, \mathrm{Ar}-\mathrm{CH}_{3}\right) ; 3.72(\mathrm{~s}$, $\left.3 \mathrm{H}, 8-\mathrm{OCH}_{3}\right) ; 6.24(\mathrm{~d}, 1 \mathrm{H}, \mathrm{J}=10 \mathrm{~Hz}, 2-\mathrm{H}) ; 6.78(\mathrm{~d}, 1 \mathrm{H}, \mathrm{J}=10 \mathrm{~Hz}, 3-\mathrm{H}) ; 13.44(\mathrm{~s}, 1 \mathrm{H}, 5-\mathrm{OH}) .{ }^{13} \mathrm{C}-\mathrm{NMR}$ $\delta\left(\mathrm{CDCl}_{3}\right): 11.39 ; 14.77 ; 27.09 ; 38.15 ; 61.49 ; 112.36 ; 124.13 ; 124.84 ; 137.88 ; 139.43 ; 149.29 ; 157.10 ; 160.76$; 190.92. P.F.: $82.1-84.3^{\circ} \mathrm{C}$. IR (KBr) $v / \mathrm{cm}^{-1}$ : $1655.95 ; 2848.23 ; 2920.58 ; 2972.67 ; 3001.61 ; 3042.12 ; 3441.48$. HRMS Calculated: 246.1256; found: 246.1265.

\subsection{Computational Calculations}

The calculations were carried out using the Gaussian 09 [44] program package (Revision a.01; Gaussian, Inc.: Wallingford, CT, USA). No symmetry constraints were imposed on the optimizations, which were performed at the DFT B3LYP/6-311++G $(d, p)$ level. No imaginary vibrational frequencies were found at the optimized geometries, indicating that they are true minima of the potential energy surface. NBO analysis was performed using the NBOPro 6.0 [45] program package (NBO 6.0; University of Wisconsin: Madison, WI, USA). QTAIM analysis was performed using the AIM2000 [46] program package (Büro für innovative software, Bielefeld, Germany).

\section{Conclusions}

In this work, we found that $\mathrm{O} \cdots \mathrm{H}$ distance is the most suitable geometrical parameter for distinguishing among IMHBs of similar strengths. Second order stabilization energies $\Delta \mathrm{E}_{\mathrm{ij}}{ }^{(2)}$ from NBO analysis and hydrogen bond energy $\left(\mathrm{E}_{\mathrm{HB}}\right)$ obtained from QTAIM analysis were also able to properly distinguish among IMHBs in the studied molecule series. In all cases, $\Delta \mathrm{E}_{\mathrm{ij}}{ }^{(2)}$ from NBO give values for the IMHB lower than $\mathrm{E}_{\mathrm{HB}}$ obtained from QTAIM analysis. $\Delta \mathrm{E}_{\mathrm{ij}}{ }^{(2)}$ are slightly below $30 \mathrm{kcal} / \mathrm{mol}$, while $\mathrm{E}_{\mathrm{HB}}$ from QTAIM gave values somewhat above $30 \mathrm{kcal} / \mathrm{mol}$, which are approximately twice of those calculated by the open-close method. In all cases, parameters calculated using $\omega$ B97XD gave the best correlations with experimental ${ }^{1} \mathrm{H}-\mathrm{NMR}$ chemical shifts for the IMHBs, with values of $\mathrm{R}^{2}$ around 0.89 . Despite this, the results showed that the employed parameters correctly described the strength of the IMHB, when the weakest one was removed from the analysis, correlations improved significantly to values around 0.95 for $\mathrm{R}^{2}$. These results can help to select the most suitable parameters for modeling molecules with IMHBs of similar strengths and achieving an adequate distinction between them through computational calculations.

Author Contributions: Conceptualization, M.M.-C. (Maximiliano Martínez-Cifuentes) and R.A.-M.; methodology, M.M.-C. (Maximiliano Martínez-Cifuentes) and R.A.-M.; software M.M.-C. (Maximiliano Martínez-Cifuentes) and M.M.-C. (Matías Monroy-Cárdenas); validation, M.M.-C. (Maximiliano Martínez-Cifuentes), R.A.-M., and B.E.W.-L.; formal analysis, M.M.-C. (Maximiliano Martínez-Cifuentes), R.A.-M., and B.E.W.-L.; investigation, M.M.-C. (Matías Monroy-Cárdenas), J.P.M-V., and R.A.-M.; writing-original draft preparation, M.M.-C. (Maximiliano Martínez-Cifuentes) and R.A.-M.; writing-review and editing, M.M.-C. (Maximiliano Martínez-Cifuentes), R.A-M., and B.E.W.-L.; project administration, M.M.-C. (Maximiliano Martínez-Cifuentes) and R.A.-M.; funding acquisition, M.M.-C. (Maximiliano Martínez-Cifuentes), R.A.-M., and B.E.W.-L.

Funding: This research was funded by Fondo Nacional de Desarrollo Científico y Tecnológico (FONDECYT), grant number 11170142 (M.M.-C. (Maximiliano Martínez-Cifuentes)) and 1180069 (R.A.-M.).

Acknowledgments: Powered@NLHPC: this research was partially supported by the supercomputing infrastructure of the NLHPC (ECM-02). R.A-M thanks Programa de Investigación Asociativa en Cáncer Gástrico (PIA-CG), Universidad de Talca, Talca.

Conflicts of Interest: The authors declare no conflict of interest. 


\section{References}

1. Arunan, E.; Desiraju, G.R.; Klein, R.A.; Sadlej, J.; Scheiner, S.; Alkorta, I.; Clary, D.C.; Crabtree, R.H.; Dannenberg, J.J.; Hobza, P.; et al. Defining the hydrogen bond: An account (IUPAC Technical Report). Pure Appl. Chem. 2011, 83, 1619-1636. [CrossRef]

2. Grabowski, S.J. What Is the Covalency of Hydrogen Bonding? Chem. Rev. 2011, 111, 2597-2625. [CrossRef]

3. Pairas, G.N.; Tsoungas, P.G. H-Bond: The Chemistry-Biology H-Bridge. Chemistryselect 2016, 1, 4520-4532. [CrossRef]

4. Giordanetto, F.; Tyrchan, C.; Ulander, J. Intramolecular Hydrogen Bond Expectations in Medicinal Chemistry. ACS Med. Chem. Lett. 2017, 8, 139-142. [CrossRef] [PubMed]

5. Kuhn, B.; Mohr, P.; Stahl, M. Intramolecular Hydrogen Bonding in Medicinal Chemistry. J. Med. Chem. 2010, 53, 2601-2611. [CrossRef]

6. Rezai, T.; Bock, J.E.; Zhou, M.V.; Kalyanaraman, C.; Lokey, R.S.; Jacobson, M.P. Conformational flexibility, internal hydrogen bonding, and passive membrane permeability: Successful in silico prediction of the relative permeabilities of cyclic peptides. J. Am. Chem. Soc. 2006, 128, 14073-14080. [CrossRef] [PubMed]

7. Alex, A.; Millan, D.S.; Perez, M.; Wakenhut, F.; Whitlock, G.A. Intramolecular hydrogen bonding to improve membrane permeability and absorption in beyond rule of five chemical space. Medchemcomm 2011, 2, 669-674. [CrossRef]

8. Caron, G.; Vallaro, M.; Ermondi, G. High throughput methods to measure the propensity of compounds to form intramolecular hydrogen bonding. Medchemcomm 2017, 8, 1143-1151. [CrossRef]

9. Afonin, A.V.; Sterkhova, I.V.; Vashchenko, A.V.; Sigalov, M.V. Estimating the energy of intramolecular bifurcated (three-centered) hydrogen bond by X-ray, IR and H-1 NMR spectroscopy, and QTAIM calculations. J. Mol. Struct. 2018, 1163, 185-196. [CrossRef]

10. Shahi, A.; Arunan, E. Hydrogen bonding, halogen bonding and lithium bonding: An atoms in molecules and natural bond orbital perspective towards conservation of total bond order, inter- and intra-molecular bonding. Phys. Chem. Chem. Phys. 2014, 16, 22935-22952. [CrossRef]

11. Tang, S.S.; Tsona, N.T.; Du, L. Ring-Size Effects on the Stability and Spectral Shifts of Hydrogen Bonded Cyclic Ethers Complexes. Sci. Rep.-UK 2018, 8, 11. [CrossRef] [PubMed]

12. Feng, L.; Bai, F.Q.; Wu, Y.; Zhang, H.X. Does the molecular structure of $\mathrm{CaH} 2$ affect the dihydrogen bonding in $\mathrm{CaH} 2$ center dot center dot center dot $\mathrm{HY}(\mathrm{Y}=\mathrm{CH} 3, \mathrm{C} 2 \mathrm{H} 3, \mathrm{C} 2 \mathrm{H}, \mathrm{CN}$, and $\mathrm{NC})$ complexes? A quantum chemistry study using MP2 and B3LYP methods. Sci. China Chem. 2012, 55, 262-269. [CrossRef]

13. Martinez-Cifuentes, M.; Cardona, W.; Saitz, C.; Weiss-Lopez, B.; Araya-Maturana, R. A Study about Regioisomeric Hydroquinones with Multiple Intramolecular Hydrogen Bonding. Molecules 2017, 22, 593. [CrossRef] [PubMed]

14. Urra, F.A.; Munoz, F.; Cordova-Delgado, M.; Ramirez, M.P.; Pena-Ahumada, B.; Rios, M.; Cruz, P.; Ahumada-Castro, U.; Bustos, G.; Silva-Pavez, E.; et al. FR58P1a; a new uncoupler of OXPHOS that inhibits migration in triple-negative breast cancer cells via Sirt1/AMPK/beta 1-integrin pathway. Sci. Rep.-UK 2018, 8, 16. [CrossRef]

15. Urra, F.A.; Córdova-Delgado, M.; Lapier, M.; Orellana-Manzano, A.; Acevedo-Arévalo, L.; Pessoa-Mahana, H.; González-Vivanco, J.M.; Martínez-Cifuentes, M.; Ramírez-Rodróguez, O.; Millas-Vargas, J.P.; et al. Small structural changes on a hydroquinone scaffold determine the complex I inhibition or uncoupling of tumoral oxidative phosphorylation. Toxicol. Appl. Pharmacol. 2016, 291, 46-57. [CrossRef] [PubMed]

16. Urra, F.A.; Martínez-Cifuentes, M.; Pavani, M.; Lapier, M.; Jaña-Prado, F.; Parra, E.; Maya, J.D.; Pessoa-Mahana, H.; Ferreira, J.; Araya-Maturana, R. An ortho-carbonyl substituted hydroquinone derivative is an anticancer agent that acts by inhibiting mitochondrial bioenergetics and by inducing G2/M-phase arrest in mammary adenocarcinoma TA3. Toxicol. Appl. Pharmacol. 2013, 267, 218-227. [CrossRef] [PubMed]

17. Fuentes, M.; Araya-Maturana, R.; Palomo, I.; Fuentes, E. Platelet mitochondrial dysfunction and mitochondria-targeted quinone-and hydroquinone-derivatives: Review on new strategy of antiplatelet activity. Biochem. Pharmacol. 2018, 156, 215-222. [CrossRef]

18. Dobado, J.A.; Gomez-Tamayo, J.C.; Calvo-Flores, F.G.; Martinez-Garcia, H.; Cardona, W.; Weiss-Lopez, B.; Ramirez-Rodriguez, O.; Pessoa-Mahana, H.; Araya-Maturana, R. NMR assignment in regioisomeric hydroquinones. Magn. Reson. Chem. 2011, 49, 358-365. [CrossRef] 
19. Salazar, R.; Vidal, J.; Martínez-Cifuentes, M.; Araya-Maturana, R.; Ramírez-Rodríguez, O. Electrochemical characterization of hydroquinone derivatives with different substituents in acetonitrile. New J. Chem. 2015, 39, 1237-1246. [CrossRef]

20. Martinez-Cifuentes, M.; Salazar, R.; Escobar, C.A.; Weiss-Lopez, B.E.; Santos, L.S.; Araya-Maturana, R. Correlating experimental electrochemistry and theoretical calculations in 2'-hydroxy chalcones: The role of the intramolecular hydrogen bond. RSC Adv. 2015, 5, 50929-50937. [CrossRef]

21. Rodriguez, J.; Olea-Azar, C.; Cavieres, C.; Norambuena, E.; Delgado-Castro, T.; Soto-Delgado, J.; Araya-Maturana, R. Antioxidant properties and free radical-scavenging reactivity of a family of hydroxynaphthalenones and dihydroxyanthracenones. Bioorgan. Med. Chem. 2007, 15, 7058-7065. [CrossRef] [PubMed]

22. Li, X.C.; Chen, B.; Xie, H.; He, Y.H.; Zhong, D.W.; Chen, D.F. Antioxidant Structure-Activity Relationship Analysis of Five Dihydrochalcones. Molecules 2018, 23, 1162. [CrossRef] [PubMed]

23. Lown, J.W. Molecular mechanisms of action of anticancer agents involving free radical intermediates. Adv. Free Radic. Biol. Med. 1985, 1, 225-264. [CrossRef]

24. Pedroza, D.A.; De Leon, F.; Varela-Ramirez, A.; Lema, C.; Aguilera, R.J.; Mito, S. The cytotoxic effect of 2-acylated-1,4-naphthohydroquinones on leukemia/lymphoma cells. Bioorg. Med. Chem. 2014, 22, 842-847. [CrossRef] [PubMed]

25. Yang, J.T.; Li, Z.L.; Wu, J.Y.; Lu, F.J.; Chen, C.H. An Oxidative Stress Mechanism of Shikonin in Human Glioma Cells. PLoS ONE 2014, 9, 12. [CrossRef] [PubMed]

26. Loya, S.; Bakhanashvili, M.; Kashman, Y.; Hizi, A. Peyssonol-A and Peyssonal-B, 2 novel inhibitors of the reverse transcriptases of human-immunodeficiency-virus type-1 and type-2. Arch. Biochem. Biophys. 1995, 316, 789-796. [CrossRef] [PubMed]

27. Arunan, E.; Desiraju, G.R.; Klein, R.A.; Sadlej, J.; Scheiner, S.; Alkorta, I.; Clary, D.C.; Crabtree, R.H.; Dannenberg, J.J.; Hobza, P.; et al. Definition of the hydrogen bond (IUPAC Recommendations 2011). Pure Appl. Chem. 2011, 83, 1637-1641. [CrossRef]

28. Castro, C.G.; Santos, J.G.; Valcarcel, J.C.; Valderrama, J.A. Kinetic study of the acid-catalyzed rearrangement of 4-acetyl-3,3-dimethyl-5-hydroxy-2-morpholino-2,3-dihydrobenzo[b]furan. J. Org. Chem. 1983, 48, 3026-3029. [CrossRef]

29. Araya-Maturana, R.; Cassels, B.K.; Delgado-Castro, T.; Valderrama, J.A.; Weiss-Lopez, B.E. Regioselectivity in the Diels-Alder reaction of 8,8-dimethylnaphthalene-1,4,5(8H)-trione with 2,4-hexadien-1-ol. Tetrahedron 1999, 55, 637-648. [CrossRef]

30. Viglianisi, C.; Bartolozzi, M.G.; Pedulli, G.F.; Amorati, R.; Menichetti, S. Optimization of the Antioxidant Activity of Hydroxy-Substituted 4-Thiaflavanes: A Proof-of-Concept Study. Chem. Eur. J. 2011, 17, 12396-12404. [CrossRef]

31. Araya-Maturana, R.; Delgado-Castro, T.; Garate, M.; Ferreira, J.; Pavani, M.; Pessoa-Mahana, H.; Cassels, B.K. Effects of 4,4-dimethyl-5,8-dihydroxynaphtalene-1-one and 4,4-dimethyl-5,8-dihydroxytetralone derivatives on tumor cell respiration. Bioorgan. Med. Chem. 2002, 10, 3057-3060. [CrossRef]

32. Cassis, R.; Scholz, M.; Tapia, R.; Valderrama, J.A. Dienone-phenol rearrangement of naphthalenetriones-a route to 10-acetoxy-5,6,7,8-tetrahydrophenanthrene-1,4-diones. J. Chem. Soc. Perk. T 1987, 2855-2859. [CrossRef]

33. Almodovar, I.; Ramirez-Rodriguez, O.; Barriga, A.; Rezende, M.C.; Araya-Maturana, R. Electrospray ionization mass spectrometric fragmentation of hydroquinone derivatives. Rapid. Commun. Mass. Spectrom. 2011, 25, 370-378. [CrossRef]

34. Becke, A.D. Density-functional thermochemistry. 3. The role of exact exchange. J. Chem. Phys. 1993, 98, 5648-5652. [CrossRef]

35. Lee, C.T.; Yang, W.T.; Parr, R.G. Development of the colle-salvetti correlation-energy formula into a functional of the electron-density. Phys. Rev. B 1988, 37, 785-789. [CrossRef]

36. Miehlich, B.; Savin, A.; Stoll, H.; Preuss, H. Results obtained with the correlation energy density functionals of becke and Lee, Yang and Parr. Chem. Phys. Lett. 1989, 157, 200-206. [CrossRef]

37. Zhao, Y.; Truhlar, D.G. The M06 suite of density functionals for main group thermochemistry, thermochemical kinetics, noncovalent interactions, excited states, and transition elements: Two new functionals and systematic testing of four M06-class functionals and 12 other functionals. Theor. Chem. Acc. 2008, 120, 215-241. [CrossRef] 
38. Chai, J.D.; Head-Gordon, M. Long-range corrected hybrid density functionals with damped atom-atom dispersion corrections. Phys. Chem. Chem. Phys. 2008, 10, 6615-6620. [CrossRef]

39. Schuster, P.; Zundel, G.; Sandorfy, C. The Hydrogen Bond, Recent Development in Theory and Experiment; North Holland Publ. Co.: Amsterdam, The Netherland, 1976.

40. Jablonski, M. Full vs. constrain geometry optimization in the open-closed method in estimating the energy of intramolecular charge-inverted hydrogen bonds. Chem. Phys. 2010, 376, 76-83. [CrossRef]

41. Espinosa, E.; Molins, E.; Lecomte, C. Hydrogen bond strengths revealed by topological analyses of experimentally observed electron densities. Chem. Phys. Lett. 1998, 285, 170-173. [CrossRef]

42. Espinosa, E.; Alkorta, I.; Elguero, J.; Molins, E. From weak to strong interactions: A comprehensive analysis of the topological and energetic properties of the electron density distribution involving X-H center dot center dot center dot F-Y systems. J. Chem. Phys. 2002, 117, 5529-5542. [CrossRef]

43. Rusinska-Roszak, D. Energy of Intramolecular Hydrogen Bonding in ortho-Hydroxybenzaldehydes, Phenones and Quinones. Transfer of Aromaticity from ipso-Benzene Ring to the Enol System(s). Molecules 2017, 22, 481. [CrossRef] [PubMed]

44. Frisch, M.J.; Trucks, G.W.; Schlegel, H.B.; Scuseria, G.E.; Robb, M.A.; Cheeseman, J.R.; Scalmani, G.; Barone, V.; Mennucci, B.; Petersson, G.A.; et al. Gaussian 09; revision A.01; Gaussian, Inc.: Wallingford, CT, USA, 2009.

45. Glendening, E.D.; Badenhoop, J.K.; Reed, A.E.; Carpenter, J.E.; Bohmann, J.A.; Morales, C.M.; Landis, C.R.; Weinhold, F. NBO 6.0; University of Wisconsin: Madison, WI, USA, 2013.

46. Biegler-Konig, F.; Schonbohm, J. Update of the AIM2000-program for atoms in molecules. J. Comp. Chem. 2002, 23, 1489-1494. [CrossRef] [PubMed]

Sample Availability: Samples of the compounds are available from the authors.

(C) 2019 by the authors. Licensee MDPI, Basel, Switzerland. This article is an open access article distributed under the terms and conditions of the Creative Commons Attribution (CC BY) license (http:/ / creativecommons.org/licenses/by/4.0/). 